\title{
Correlates of emergency response interval and mortality from severe aniemia in childhood
}

\author{
*S. K. Ernest, N. E. Anunobi and A. Adeniyi \\ Department of Paediatrics and Child Health, \\ University of Ilorin and University of Ilorin Teaching Hospital, Ilorin Nigeria.
}

\begin{abstract}
Summary
A retrospective study to determine the influence of blood transfusion emergency response interval on Mortality from childhood severe anaemia was carried out. Admission records of all children with severe anaemia over a 5 -year period was reviewed. Those who either died before transfusion or got discharged against medical advice were excluded. A total of 5790 patients were admitted during the 5 year period. Ten percent $(10 \%)$ had severe anaemia. Malaria, the leading cause of anaemia in this series, was found in $80 \%$ of the patients. Twenty patients (3.3\%) died before transfusion while 50 discharged from the hospital against medical advice. There was male preponderance. Ages 2-5 years were the peak age group for severe anaemia. No patient had haematocrit less than $5 \%$ but $20(4.2 \%)$ had henematocrit above $20 \%$. The hospital stay for majority $(\mathbf{7 4 . 8} \%)$ of the patients was 72 hours or less. Mortality (Case fatality) increases with increase in transfusion emergency response interval with in 24 hours. Based on the transfusion emergency response interval versus mortality curve, a mortality risk assessment scores were derived for use in clinical practice to determine the risk of dying from the disease. We recommend that national or hospital policy on blood transfusion be enunciated to ensure that all patient with severe anaemia get transfused within 2 hours of diagnosis.
\end{abstract}

Keywords: Transfusion Emergency response interval, Mortality, Mortality risk assessment scores.

\section{Résumé}

Une étude rétrospective pour examiner l'influence de la réaction par intervalles de la transfusion du sang d'urgence sur la mortalité à travers l'anemie infantile grave, a été effectuée.

Enregistrement d'admission de tous les enfants souffrant de l'anémie grave au cours d'une période de 5 ans a été passé en revue, à l'exception de ceux qui étaient morts soit avant la transfusion soit ceux qui étaient sorti de l'hôpital san permission. Un nombre total de 5,790 malades ont été hospitalisés au cours de cette période de cinq ans. Dix pourcent $(10 \%)$ avaient l'anémie grave. Le paludisme, qui prend la tête dans la cause de l'anémie en cette série était noté chez des malades, vingt malades soit $(3,3 \%)$ étaient morts avant la transfusion tandis que 50 avaient quitté l'hôpital sans la consultation médicale.

On avait remarqué la prépondérance de mâle. Le groupe de la classe 2 à 5 ans était l'âge maximum pour l'attaque de l'anémie grave. Aucun malade avait l'hématocrit, moins de $5 \%$ mais 20 soit $(4,2 \%)$ avaient l'hématocrit plus de $20 \%$. La durée de l'hospitalisation pour le plus grand nombre des malades $74,8 \%$ était 72 heures ou moins.

Le mortalité (cas montel) s'accroit avec l'accrossement de la transfusion d'urgence réaction par intervalles en moins de 24 heures. A travers la transfusion d'urgence reaction par intervalle par rapport à la coube de la mortalité, des scores de la répartition des risques de morts (mortality risk assessment scores) étaient tirés à l'usage des clientèle cliniques pour déterminer le risque des morts à travers la maladie. Nous proposons que la politique nationale ou de l'hôpital sur la transfusion du sang soit précise et claire pour assurer que tous les malades avec l'anémie grave recoivent la transfusion en moins de 2 heures de la diagnose.

\section{Introduction}

On several occasions children are rushed into hospitals becanse of severe anaemia from various causes. The causes a ad rate of developemnt of anaemia determine the type of treatr nent to be given. However replacement of red cell is indicated once tise anaemia becomes severe enough to compromise tissue oxygen lelivery ${ }^{1,2}$.

Packed cel volume per se is a good indicator of a raemia but not a true reflection of tissue oxygen delivery because ( if compensatory increase in cardiac output. In comparison, c inical evidences of decompensating cardiac function are more ir dicative of disease severity and potential death if anaemia is no. promptly corrected. Consequently the rapidity with which blc od can be made available to these children is a potential determin ant of survival 3,4

The purpose of this retrospective study is to er aluate the influence of the emergency response interval on the mo: tality from severe anaemia among children and identify the factors esponsible for delay in emergency response. We have observed severely anaemic children die in the hospital while waiting for blood transfusion due to delay in emergency response. W: have observed severely anaemic children die in the hospital wh ile waiting for blood transfusion due to delay in the availability of appropriate blood or its products.

In the tropics and sub-tropical regions of the $w$ orld emergency care responsiveness is slow with an attendan increased emergency response interval that may increase morta ity. Hence this present study was carried out to locate the presen it status of our emergency response to severely anaemic children and the likelihood of dying from severe anaemia.

\section{Method}

This retrospective study involved a review of the admission records of the patients with severe anaemia cared for ir the Emergency Paediatries Unit (EPU) of the University of lloria Teaching Hospital (UITH), llorin, Nigeria over a 5 year period January 1994 to 1998. Information extracted for this study inclıded: Age, sex, date of admission, time of diagnosis, time of com nencement of blood transfusion, the causes of anaemia and the treatment outcome. The 20 patients who died before transfusion and the 50 patients who were discharged against medical advice wer e excluded. Data was entered into IBM compatible personal computer. Analysis was done on Epi Info version 6.02 and emergen y response interval versus mortality curve was designed using Micr. soft Excel ${ }^{5}$.

\section{Result}

A total of 5790 patient were admitted into the EPI over the 5 year period. Six hundred $(600)$ had severe anaemia dus to various conditions. Incidence of severe anaemia was $10.4 \%$. F fly patients $(50,8.3 \%)$ were discharged against medical advise (T'AMA) and twenty $(20,3.3 \%)$ died before transfusion while the rer 1 aining five hundred and thirty $(530,88.4 \%)$ received blood transfu ion. There was male preponderance. Male 335 (53\%). Female 265 (45\%) with a male to female ratio of 1:0.7. Forty patients dieci among the 530 patients in consideration due to anaemic heart failure and hypoxic encephalopathy. Case fatality was $7.6 \%$.

Among the 120 patients that had blood transfusion within 2 
hours of diagnosis $1(0.8 \%)$ died and $119(99.2 \%)$ survived. One hundred and ninety eight (198) were transfused within 3-6 hours of diagnosis, 4 (2\%) died and 194 (98\%) survived. Ninety patients were transfused within 7-10 hours of diagnosis $7(7.8 \%)$ died and $83(92.2 \%)$ survived. Also, of the 54 patients that were transfused within 11-15 hours of diagnosis 9 (116.7\%) died and 45 (83.3\%) were alive. Of the 38 patients that were transfused within 16-20 hours of diagnosis $10(26.3 \%)$ died and $28(73.7 \%)$ survived. Among the 17 patients that were transfused within 21-24 hours of diagnosis $6(35.2 \%)$ died and $11(64.8 \%)$ were alive while of the remaining 13 patients that were transfused after 24 hours of diagnosis $3(23.1 \%)$ died and $10(76.9 \%)$ survived. (Table 1 ).

Table 1 Emergency response interval and mortality from severe anaemia

\begin{tabular}{llrrrr}
\hline $\begin{array}{l}\text { Interval } \\
\text { (Hours) }\end{array}$ & Number & $\begin{array}{c}\text { Outcome } \\
\text { Number alive }\end{array}$ & \% & Death & $\%$ \\
$1-2$ & 120 & 119 & 99.2 & 1 & 0.8 \\
$3-6$ & 198 & 194 & 98 & 4 & 2.0 \\
$7-10$ & 90 & 83 & 92.2 & 7 & 7.8 \\
$11-15$ & 54 & 45 & 83,3 & 9 & 16.7 \\
$16-20$ & 38 & 28 & 73.7 & 10 & 26.3 \\
$21-24$ & 17 & 11 & 64.8 & 6 & 35.2 \\
$>24$ & 13 & 10 & 76.9 & 3 & 23.1 \\
Total & 530 & 490 & & 40 & \\
\hline
\end{tabular}

Figure 1 emergency response interval versus mortality curve shows increase mortality with increase interval. The mortality at different reaction time were compared for significant differences, at $<6$ hours versus $>6$ to 10 hours Chi squared was 9.04, P-value was 0.003 and odds ratio was 5.1. At $>6-10$ hours versus $>10$ hour -24 hour Chi squared was $6.17, \mathrm{P}$-value was 0.013 and odds ratio was 2.95. At $<10$ hour versus $>10-24$ hours Chi squared was $40.69, P$-value was 0.000 and odds ratio was 7.8 and $<24$ hours versus $>24$ hours Chi squared was $3.47, \mathrm{P}$-value was 0.09 and odds ratio was 0.31 (Table 2).

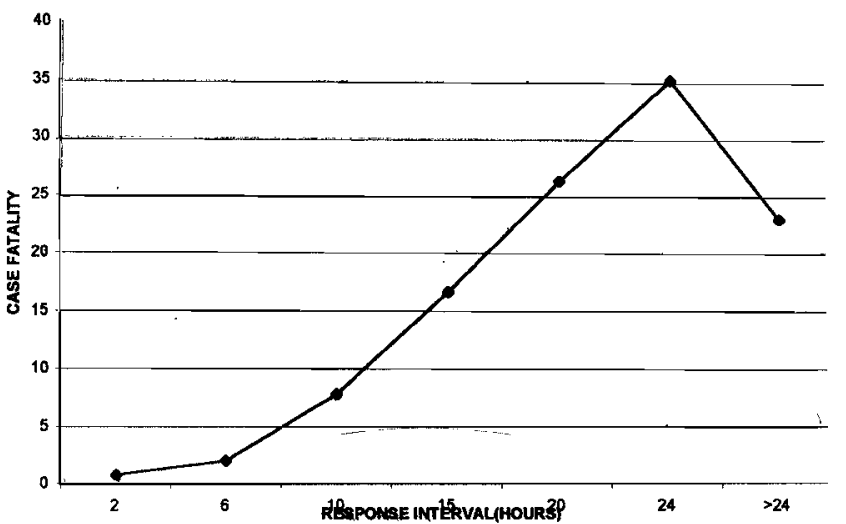

Fig. 1 Correlates of transfusion emergency response interval and mortality from severe anaemia in childhood (response interval versus mortality curve)

Table 2 Comparism of mortality at different emergency response interval

\begin{tabular}{lrrrl}
\hline $\begin{array}{l}\text { Interval(Hours) } \\
\text { Difference }\end{array}$ & Chi-Square & P-value & Odds Ratio \\
$<6$ versus $>6-10$ & 9.04 & 0.003 & 5.1 & Significant \\
$>6-10$ versus $>10-24$ & 6.17 & 0.013 & 2.95 & Significant \\
$<10$ versus $>10-24$ & 40.69 & 0.000 & 7.8 & Significant \\
$<24$ versus $>24$ & 3.47 & 0.09 & 0.31 & Not significant \\
\hline$P$-value $<0.05$ is significant & & & &
\end{tabular}

The distribution of the patients by age was as on Table 3 . Infants were 170 (28.3\%), age group 2-5 years were 345 (57.5\%) age group 6-12 years were 75 (12.5\%), while age group 13-15 years were $10(1.7 \%)$.

Table 3 Distribution of severe anaemic patients

\begin{tabular}{lrr}
\hline Age (Years) & Number & $\%$ \\
$<1$ & 170 & 28.3 \\
$2-5$ & 345 & 57.5 \\
$6-12$ & 75 & 12.5 \\
$13-15$ & 10 & 1.7 \\
Total & 600 & 100 \\
\hline
\end{tabular}

The distribution of the patients by haematocrit $(\mathrm{Ht})$ were as follows (Table 4). No patient had haematocrit $<5 \%, 140(23.3 \%)$ patients had haematocrits between 6-10\%, $235(39.2 \%)$ had $11-$ $15 \%$ haematocrit, $200(33.3 \%)$ had haematocrit of $16-20 \%$ ) while $25(4.2 \%)$ had haematocrit greater than $20 \%$.

Table 4 Distribution of severe anaemic patients by haematocrit Haematocrit (\%) Number

$<5$

6-10

11-15

16-20

$>20$

Total

$\begin{array}{rr}0 & 0 \\ 140 & 23.3 \\ 235 & 39.2 \\ 200 & 33.3 \\ 25 & 4.2 \\ 600 & 100\end{array}$

The causes of anaemia were as follows; malaria in $480(80 \%)$ patients, sickle cell anaemia in $150(25 \%)$ patients, protein calory malnutrition in $120(20 \%)$ patients, septicaemia in $100(16.7 \%)$ patients, bronchopneumonia in $96(16 \%)$ patients, glucose- 6 -phosphate dehydrogenase deficiency in $22(3.6 \%)$ patients, autoimmune haemolytic anaemia in $12(2 \%)$ patients, leukemia in $8(1.3 \%)$ patients and disseminated intravascular coagulation due to snake bite poisoning in $3(0.5 \%)$ patients (Table 5 ).

Table 5 Causes of severe anamia among 600 children

Causes *Number \%

Malaria $\quad 480 \quad 80$

Sickle cell anaemia

$150 \quad 25$

Protein Energy Malnutrition $\quad 120$

Septicaemia

Bronchopneumonia

G-6-P-D deficiency

Autoimmune haemolytic anaemia

Leukemia

100

16.7

DIC due too snake bite poisoning**

*Some patients had multiple diagnosis

**DIC = Disseminated intravascular coagulopathy

Table 6 Duration of hospital stay

\begin{tabular}{lcc}
\hline Days & Number & $\%$ \\
$1-3$ & 449 & 74.8 \\
$4-7$ & 90 & 15.0 \\
$8-14$ & 7 & 1.2 \\
$>14$ & 3 & 0.5 \\
Total & $550^{*}$ & 100 \\
\hline
\end{tabular}

${ }^{*}$ Excluding those that discharge against medical advise

Table 7 Mortality risk assessment score (M-RAS) in severe childhood anaemia

Response interval Risk of death

$\begin{array}{lll}\text { Hours } & \text { (Mortality risk) Scores }\end{array}$

$<2$

2-6

6-10

$10-24$

RI-Almost NIL

R2-Low

R3-Moderate

R4-High

$>24$

R5-Very High

1
2
3
4
5


The duration of hospital stay was as presented on Table VI, $440(74.8 \%)$ patients spent between 1 to 3 days, 90 (15\%) patients spent 4 to 7 days, $7(1.2 \%)$ patients spent 1 to 2 weeks while $3(0.5 \%)$ spent more than 2 woeks in the hospital.

\section{Discussion}

Emergency response interval takes into consideration the period between diagnosis and the time of onset of blood transfusion which usually may not be truly representative of the time patient expended in the hospital. Much time may be spent on consultation bureaucracies like retrieving record folder, making payments and waiting to take turn to see the doctor all of which could not be represented in the records. However, as noted by Bamigboye et $\mathrm{al}^{6}$, the time spent in the hospital may be lengthened or shortened by many factors.

The prevalence of severe anaemia of $10.5 \%$ is comparable experiences from other local centers in Nigeria and to that of $7.8 \%$ reported from Vermont initially but much higher than the $3.6 \%$ reported later from the same center ${ }^{7}$. This variation can be attributable to the high prevalence of sickle cell anaemia, malnutrition, and malaria and infestations in our environment. There was increase case fatality (CF) with increase emergency response interval. This correlation continues until 24 hours reaction time, after which $\mathrm{CF}$ falls. This is consistent with logical thinking and previous findings ${ }^{2,4}$.

Our study showed an emergency response interval versus mortality curve with significant prognostic outlook that is suggestive of a graded risk of death at different intervals. We therefore suggest a mortality risk assessment score (M-RAS). Scores were as follows; 1 for almost no risk of death, 2 for low risk, 3 for moderate risk, 4 for high risk and 5 for very high risk, (Table 7).

To minimise fatality, transfusion must be given within 3 hours of diagnosis. Within 6 hours emergency response interval risk of dying is low and this steadily increases as emergency response interval increases. The M-RAS can therefore be used to communicate death risk on individual patient to the minds of health planners and the physicians and the urgent need to reduce reaction time and hence mortality, through transfusion policy and improved quality of standard care.

However, the observed decline in the CF among the patient whose transfusion inadvertently got delayed beyond 24 hour emergency response interval showed no statistically significant difference from the mortality within 24 hours. The decline may be related to the therapy from better medical opinion which was not available for those who died within 24 hours emergency response interval. Such therapy included administration of frusemide to reduce pre-load on the heart. The quality of care usually improved steadily over 72 hours of admission due to opinions from case reviews by higher cadre physicians. However, no standard of care should transfuse any patient later than 24 hours of diagnosis.

Most of the patients were discharged within 72 hours of admission. This is understandable because the leading cause of severe anaemia was malaria which is treatable within that period; once the child has been transfused they may be discharged to complete anti-malaria therapy at home if not completed yet. The reason why no one came with heamatocrits less than $5 \%$, may be because they died at home. It could then be concluded that such haematocrit is not compatible with life in our environment. At that low haematocrit the level of hypoxia could result not only into sardiac malfunctioning but also encephalopathy and adren spathy and eventual death ${ }^{8}$.

The age distribution of anaemia Table 2 shows that ace group 2-5 years were most vulnerable. Infants were likely to have some protection from their mother and less predisposed to having malaria or malnutrition because most got exclusively broast fed. At the age group 2-5 years when nutrition is no longer a lequate and malaria immunity has remarkably waned off form the circulation then severe malaria and bacterial infection are most lik ely to occur at that time. The leading cause of anaemia and the ipectrum of diseases responsible for severe anaemia were compara ble to previously reported in our environment ${ }^{9}$.

We suggest that more aggression be shown to redur e the Blood Transfusion emergency response interval to reduce ase fatality from severe anaemia most especially in the vulnerat le ages. A hospital policy that will enable transfusion to be under aken within 2 hours of diagnosis is desirable. Also further researcl s should be carried out to address issues that may be responsible $f$ th the delay in transfusion that may cause unnecessarily prolonged emergency response interval.

\section{References}

1. Silver HK, Kempe CH and Bruyn HB. Blond. In: Iandlook of Paediatrics by Lange Medical Publications, Los Allos, California, $14^{\text {th }}$ eds. $1983 ; 387-415$.

2. Bove JR. Practical Blood Transfusion $3^{\text {rd }}$ eds. B ston, Little brown, 1986.

3. Bucholz DM. Paediatric Transfusion Therapy J. Pa adiatr 1974; $84: 1$.

4. Pearson HA. Disease of the blood. In: Nelson ' extbook of paediatrics by Behrman RE and Vaughan VC. U B Saunders Company (publ) $13^{\text {th }}$ eds. $1987: 1033-1078$.

5. Dean AG, Dean JA, Coulombier D, Brendel KA, Smith DC, Burton AH, Dicker RC, Sullivan K, Fogan RF an!l Amer TC. Epi Info, Versin 6.02: a word processing database, : nd statistics program for epidemiology on microcomputers, thanta GA. Centre for Disease Control 1994.

6. Bamigboye EA, Erinoso $\mathrm{HO}$ and Ogunlesi AO. The waiting time at the Children's Emergency Room, univers ity College Hospital, Ibadan, Nigerian Journal of Paediatrics 1592: 19(1) 0 $-14$.

7. Sherry B, Bister D and Yip R. Continuation ol decline in prevalence of anemia in low income children: the Vermont experience. Arch. Pediatr Adolesc. Med. 1997: 159 (9): 928930.

8. Overall JC. Hypoxia-Ischemia. In: Nelson Textbr ok of Pediatrics by Behmman RE and Vaughan VC. W.B. Sa nders Company (publ) $13^{\text {th }}$ eds. 1987 : $390-391$.

9. Marshk K. Immunology of human malaria. In: Bin ce-Chwatt's Essential Malariology by Gilles HM and Warrel I A, Edward Arnold (publ) London, Boston, Melbourne, Auckl ind, $3^{\text {rd }}$ eds 1993: $60-77$ 